\title{
Dynamics of a Floating Exchange Rate Regime
}

\section{Citation}

Helpman, Elhanan, and Assaf Razin. 1982. Dynamics of a floating exchange rate regime. Journal of Political Economy 90(4): 728-754.

\section{Published Version}

doi:10.1086/261086

\section{Permanent link}

http://nrs.harvard.edu/urn-3:HUL.InstRepos:3445095

\section{Terms of Use}

This article was downloaded from Harvard University's DASH repository, and is made available under the terms and conditions applicable to Other Posted Material, as set forth at http:// nrs.harvard.edu/urn-3:HUL.InstRepos:dash.current.terms-of-use\#LAA

\section{Share Your Story}

The Harvard community has made this article openly available.

Please share how this access benefits you. Submit a story.

\section{Accessibility}




\section{CHICAgO JOURNALS}

Dynamics of a Floating Exchange Rate Regime

Author(s): Elhanan Helpman and Assaf Razin

Source: The Journal of Political Economy, Vol. 90, No. 4 (Aug., 1982), pp. 728-754

Published by: The University of Chicago Press

Stable URL: http://www.jstor.org/stable/1831350

Accessed: $1 1 \longdiv { / 1 2 / 2 0 0 9 \text { 16:07 } }$

Your use of the JSTOR archive indicates your acceptance of JSTOR's Terms and Conditions of Use, available at http://www.jstor.org/page/info/about/policies/terms.jsp. JSTOR's Terms and Conditions of Use provides, in part, that unless you have obtained prior permission, you may not download an entire issue of a journal or multiple copies of articles, and you may use content in the JSTOR archive only for your personal, non-commercial use.

Please contact the publisher regarding any further use of this work. Publisher contact information may be obtained at http://www.jstor.org/action/showPublisher?publisherCode=ucpress.

Each copy of any part of a JSTOR transmission must contain the same copyright notice that appears on the screen or printed page of such transmission.

JSTOR is a not-for-profit service that helps scholars, researchers, and students discover, use, and build upon a wide range of content in a trusted digital archive. We use information technology and tools to increase productivity and facilitate new forms of scholarship. For more information about JSTOR, please contact support@jstor.org.

The University of Chicago Press is collaborating with JSTOR to digitize, preserve and extend access to The Journal of Political Economy. 


\title{
Dynamics of a Floating Exchange Rate Regime
}

\section{Elhanan Helpman and Assaf Razin}

Tel-Aviv University

\begin{abstract}
We study the full equilibrium dynamics of a two-country world economy with a floating exchange rate, traded and nontraded goods, and explicit modeling of the use of money. The resulting exchange rate equation depends on several details of the economic structure, such as the supply structure and propensities to spend on various goods. Although real exchange rate movements have the usual association with the current account, the ordinary exchange rate may appreciate or depreciate when there are deficits on current account even when the quantities of money do not change. Deviations from purchasing-power parity and the Fisher equation are shown to be the rule rather than the exception.
\end{abstract}

\section{Introduction}

We study in this paper the dynamics of a simple two-country world economy with a floating exchange rate. Each country produces traded and nontraded goods. Consumers maximize the discounted flow of utilities, with the level of utility depending on consumption of traded and nontraded goods. There exist in these economies well-defined demand functions for money that are derived from the institutional structure in which money buys goods but goods do not buy goods. The use of national monies is modeled as in Stockman (1980) and Helpman (1981). This specification generates an exchange rate equa-

This is a revised version of Working Paper no. 21-81, Foerder Institute of Economic Research, Tel-Aviv University. We would like to thank Wilfred Ethier, Robert Lucas, and Lars Svensson for specific comments which we have incorporated in the present version. Useful general comments were also received in seminars at the University of Chicago, the University of Pennsylvania, and Tel-Aviv University. The Foerder Institute for Economic Research provided financial support. 
tion in which the exchange rate is equal to the relative supply of monies divided by the relative real demand for monies, where the relative demand expresses the world's relative demand for each currency. In our model the demand for a country's money derives from transaction needs and depends on the world's desired spending on goods which are produced in that country. As a result, the relative demand for monies depends not only on aggregative variables, such as wealth, but also on the details of the sectoral structure of the economies on the supply side and on propensities to spend on various goods. This novel feature stems from the microeconomics of the monetary mechanism and has, as we show, interesting implications for exchange rate dynamics. Real factors play a major role in our exchange rate equation.

The dynamics of our model are driven by savings behavior; we do not deal with investment (see, however, Helpman and Razin 1981b). We show that, during the adjustment process, deficits on current account are associated with depreciations of the real exchange rate (the price of traded goods in terms of nontraded goods), but that there exists no clear-cut association between deficits on current account and ordinary exchange rate movements. In the presence of a single traded good, deficits on current account are associated with depreciations of the exchange rate. However, if there is more than one traded good, deficits on current account may be associated with either depreciations or appreciations of the exchange rate (even in the presence of passive monetary policies). The resulting association depends on the cross-country correlation between marginal propensities to spend on each traded good and a measure of its relative availability in that country. Hence, real exchange rates and ordinary exchange rates may be either positively or negatively correlated along the adjustment path.

The behavior of GNP deflators and consumer price indices along the adjustment path is also analyzed. Using these indices, we explain deviations from purchasing-power parity and the Fisher equation, which we show to be the rule rather than the exception. Finally, we discuss the effects of both anticipated and unanticipated monetary shocks. Anticipated monetary shocks have no real effects in our model. Unanticipated changes in money supply do, however, have real effects arising from the redistribution of real wealth. This redistribution stems from capital gains and losses which arise from the existence of nominal claims (see Boyer 1977).

In Section II we describe our basic model. The equilibrium time pattern of prices, interest rates, and exchange rates is described in Section III, where we show that this equilibrium path is unique. The effects of monetary shocks are analyzed in Section IV. In Section V, 
we discuss an extended version of the model which incorporates terms of trade effects. The final section contains a selective summary and a discussion of the central role played by the monetary mechanism.

\section{The Model}

Our model is essentially the floating exchange rate regime model discussed in Helpman (1981). There are two modifications required for present purposes: $(a)$ the introduction of a nontraded good and (b) an infinite time horizon. There are two countries, a home country, $H$, and a foreign country, $F$. We assume the existence of discrete time periods $(t=0,1,2, \ldots)$. At the beginning of each period all financial markets open and operate: markets for bonds, denominated in each currency, and foreign-exchange markets. After the clearance of these markets, consumers buy goods with money. Home goods are sold for home money, while foreign goods are sold for foreign money. There is a single traded good, $T$, and each country has a single nontraded good, $N .{ }^{1}$ Output levels, $Q_{k l}, l=T, N, k=H, F$, are the same in every period $\left(Q_{F T}\right.$, e.g., is the output of the traded good in the foreign country). Firms are assumed to produce the output levels described above. During a given period they sell their output and accumulate money. At the end of the period, they distribute the accumulated money balances as factor and dividend payments. The supply of factors of production is completely inelastic. ${ }^{2}$ Home firms are owned by home residents, while foreign firms are owned by foreign residents.

Governments engage in monetary policy by transferring their country's money to their residents. The quantities of money at the beginning of period $t$ are $\bar{M}_{k t}, k=H, F$, and the evolution of these stocks is given by $\bar{M}_{k t}=M_{k}+\sum_{\tau=0}^{t} X_{k \tau}, t=0,1,2, \ldots$, where $M_{k}$ is the stock of country-k money inherited at $\tau=0$ from the past, and $X_{k \tau}$ is the monetary injections at the beginning of period $\tau$.

Each country is represented by a representative consumer who maximizes a discounted flow of utilities, where the temporal utility level depends on the consumption of traded and nontraded goods. Foreign and home traded goods are perfect substitutes in consumption. A consumer faces a sequence of budget constraints. Aggregate liquidity at the beginning of period $t$ is determined by monies carried over from the previous period, by dividend and factor payments, by monetary transfers from the government, and by borrowing net of

\footnotetext{
${ }^{1}$ We will introduce two traded goods in Sec. V in order to deal with terms of trade effects. Meanwhile, terms of trade effects are neglected.

${ }^{2}$ We discuss the effects of elastic labor supply in Sec. IV.
} 
debt repayments. This is split at the beginning of the period, via the foreign-exchange market, into home and foreign currencies. These money stocks impose liquidity constraints. Part of the money is spent on goods during the period, while the rest of it is carried forward to the next period. Home goods are bought with home money, while foreign goods are bought with foreign money. In period $t=0$, there are currency $k$-denominated debt repayments $\bar{B}_{k 0}, k=H, F$, which have been inherited by the home country from the past and which are unalterable in period $t=0$ (the foreign country's debt repayments are minus $\bar{B}_{H 0}$ and minus $\bar{B}_{F 0}$ ). Finally, there is a terminal condition on debt repayment-debt is not allowed to grow forever at a rate that exceeds the rate of interest. This is the infinite horizon analogue of full debt repayment at the end of a finite horizon. A formal description of this structure is given in Helpman and Razin (1981a).

An equilibrium of our world economy, relative to given monetary policies, consists of commodity prices $p_{k l t}, k=H, F, l=T, N$; exchange rates $e_{t}$ (the price of foreign currency in terms of home currency); and interest rates $i_{k t}, k=H, F$, such that the maximizing variables of the individual decision problems in each country satisfy market clearance. The markets which have to clear are: $(a)$ each country's nontradedgoods market, $(b)$ the world's traded-goods market, $(c)$ each country's money market (the world's demand for each currency should equal its supply), and $(d)$ the markets for each country's currencydenominated debt (the world's excess demand for each currency's denominated debt should be zero).

It can be shown (as in Helpman [1981]) that in an equilibrium of our economy, two parity conditions must be satisfied:

$$
p_{H t}=e_{t} p_{F t}
$$

and

$$
1+i_{H t}=\left(1+i_{F t}\right) e_{t+1} / e_{t},
$$

all $t=0,1, \ldots$. The first parity condition describes the law of one price for traded goods, while the second describes the interest rate parity condition.

Due to these parity conditions and the fact that there are no restrictions on debts (except for a solvency constraint), the sequence of consumer budget constraints can be reduced to a single budget constraint in which the present value of spending is smaller or equal to the present value of income net of debt, that is, wealth. In equilibrium, wealth can be represented as the present value of output minus debt. For details see Helpman (1981). Then, it can be shown that in an equilibrium with perfect foresight, the home country's consumption levels are solutions to the following problem: 
Choose

to maximize

$$
\left\{c_{T t}, c_{H N t}\right\}_{t=0}^{\infty}
$$

$$
\sum_{t=0}^{\infty} \delta_{H}^{t} u_{H}\left(c_{T t}, c_{H N t}\right)
$$

subject to

$$
\sum_{t=0}^{\infty} d_{t}\left(p_{F T t} c_{T t}+q_{H N t} c_{H N t}\right) \leqslant \sum_{t=0}^{\infty} d_{t}\left(p_{F T t} Q_{H T}+q_{H N t} Q_{H N}\right)-\left(\bar{B}_{H 0} / e_{0}\right)-\bar{B}_{F 0}
$$

and

$$
c_{T t}, c_{H N t} \geqslant 0 \text {, }
$$

where $c_{T t}=$ consumption of traded goods in period $t ; c_{H N t}=$ consumption of home nontraded goods in period $t ; \delta_{H}=$ discount factor $\left(0<\delta_{H}<1\right) ; u_{H}(\cdot)=$ utility function; $q_{H N t}=p_{H N t} / e_{t}=$ the price of home nontraded goods in terms of foreign currency; and $d_{t}=$ $\prod_{\tau=0}^{t-1}\left(1+i_{F \tau}\right)^{-1}=$ present-value factor, using foreign interest rates, with $d_{0}=1$.

Using asterisks to denote foreign decision variables, the foreign country's consumption levels are a solution to the following decision problem:

Choose

$$
\left\{c_{T t}^{*}, c_{F N t}^{*}\right\}_{t=0}^{\infty}
$$

to maximize

$$
\begin{gathered}
\sum_{t=0}^{\infty} \delta_{F}^{t} u_{F}\left(c_{T t}^{*}, c_{F N t}^{*}\right), \\
\sum_{t=0}^{\infty} d_{t}\left(p_{F T t} c_{T t}^{*}+p_{F N t} c_{F N t}^{*}\right) \leqslant \\
\text { and } \sum_{t=0}^{\infty} d_{t}\left(p_{F T t} Q_{F T}+p_{F N t} Q_{F N}\right)+\left(\bar{B}_{H 0} / e_{0}\right)+\bar{B}_{F 0} \\
\\
c_{T t}^{*}, c_{F N t}^{*} \geqslant 0 .
\end{gathered}
$$

Observe from (4) and (4') that each country's present value of spending is constrained to be less than or equal to the present value of its output, plus an indebtedness term. The indebtedness term stems from past borrowing and its net value across countries is zero; that is, the debt of one country is the credit of the other.

It is clear from problems (3) and $\left(3^{\prime}\right)$ that as of period $t=0$, the perfect-foresight equilibrium paths of consumption depend on mon- 
etary policies only to the extent that they affect the real value of the net indebtedness account $\left(\bar{B}_{H 0} / e_{0}\right)+\bar{B}_{F 0}$. This is, in fact, the single channel through which monetary policy may have real effects in our perfect-foresight world. ${ }^{3}$

It can be shown that whenever the nominal interest rate on a particular currency-denominated debt is positive, no one will use this currency for store-of-value purposes in that period (see Helpman 1981). For simplicity, we will consider only monetary policies which assure positive interest rates in each country and in every period. In this case, all money will be used for transaction purposes. Hence, the demand for a particular country's money is equal to the value of the world's demand for its goods. Since in equilibrium $(a)$ the world's demand for each currency equals its supply and $(b)$ the world's demand for each good (with nontraded goods being only locally demanded) equals its supply, these relationships imply an equality between each country's value of output and the stock of its money at the beginning of the period:

$$
e_{t}\left(p_{F T t} Q_{H T}+q_{H N t} Q_{H N}\right)=\bar{M}_{H t}
$$

and

$$
p_{F T t} Q_{F T}+p_{F N t} Q_{F N}=\bar{M}_{F t},
$$

for $t=0,1, \ldots$ Observe that $(6 a)$ relies on the law of one price (1). Here, the velocity of circulation equals one, and changes in the interest rate do not affect it as long as the interest rate stays positive. This is so because individuals already hold minimal balances necessary to finance the required level of consumption.

\section{The Time Pattern of Prices, Interest Rates, and Exchange Rates}

In order to demonstrate the dynamics of prices, interest rates, and exchange rates, we develop an explicit solution of our model. We assume the following forms of utility functions:

$$
\begin{gathered}
u_{H}\left(c_{T}, c_{H N}\right)=\alpha_{H T} \log c_{T}+\alpha_{H N} \log c_{H N}+g_{H} \\
\alpha_{H T}, \alpha_{H N}>0, \alpha_{H T}+\alpha_{H N}=1 \\
g_{H}=-\alpha_{H T} \log \alpha_{H T}-\alpha_{H N} \log \alpha_{H N}
\end{gathered}
$$

\footnotetext{
${ }^{3}$ See Sec. IV for a discussion of additional channels.
} 
and

$$
\begin{gathered}
u_{F}\left(c_{T}^{*}, c_{F N}^{*}\right)=\alpha_{F T} \log c_{T}^{*}+\alpha_{F N} \log c_{F N}^{*}+g_{F} \\
\alpha_{F T}, \alpha_{F N}>0, \alpha_{F T}+\alpha_{F N}=1 \\
g_{F}=-\alpha_{F T} \log \alpha_{F T}-\alpha_{F N} \log \alpha_{F N} .
\end{gathered}
$$

In order to solve problems (3) and (3'), we adopt a two-stage procedure. We concentrate only on problem (3), since the solution to $\left(3^{\prime}\right)$, for the foreign country, is derived in a similar way. Our procedure consists of separating the temporal allocation of spending between the two goods from the intertemporal allocation of spending. This separation is possible with the utility functions described by (7), since it yields an indirect utility function which is additively separable in prices and spending. Let

$$
Z_{t}=p_{F T t} c_{T t}+q_{H N t} c_{H N t}
$$

be the home country's spending in period $t$ in terms of foreign currency, and let

$$
W_{0}=\sum_{t=0}^{\infty} d_{t}\left(p_{F T t} Q_{H T}+q_{H N T} Q_{H N}\right)-\left(\bar{B}_{H 0} / e_{0}\right)-\bar{B}_{F 0}
$$

be the home country's net wealth in terms of foreign currency at the beginning of period zero. Observe that net wealth depends on both prices and interest rates that will prevail over the entire horizon. We assume at this stage that $W_{0}$ is finite, but we will show that this is indeed the case when we calculate the equilibrium values of prices and interest rates and the exchange rate $e_{0}$. However, $W_{0}$ is not a decision variable of the consumer at time $t=0$ (although he influenced its value in period $t=-1$ ).

The indirect utility function of $(7 a)$ is:

$$
v_{H}\left(p_{F T}, q_{H N}, Z\right)=-\alpha_{H T} \log p_{F T}-\alpha_{H N} \log q_{H N}+\log Z .
$$

Hence, the optimal allocation of spending as implied by (3) is the solution to: Choose $\left\{Z_{t}\right\}_{t=0}^{\infty}$ to maximize $\sum_{t=0}^{\infty} \delta_{H}^{t} \log Z_{t}$, subject to $\sum_{t=0}^{\infty} d_{t} Z_{t} \leqslant W_{0}, Z_{t} \geqslant 0$. The solution to this problem yields:

$$
Z_{t}=\left(1-\delta_{H}\right)\left(\frac{\delta_{H}^{t}}{d_{t}} W_{0}\right), t=0,1,2, \ldots
$$

It is easy to show that $W_{0} \delta_{H}^{t} / d_{t}$ is net wealth at the beginning of period $t^{4}{ }^{4}$ Hence, our individual spends at each period a constant fraction

\footnotetext{
${ }^{4}$ Changes in indebtedness can be directly calculated from changes in wealth (the current account). See Appendix A for the calculation, as well as for a proof that $W_{0} \delta_{H}^{t} / d_{t}$ is period- $t$ wealth.
} 
$\left(1-\delta_{H}\right)$ of his net wealth at the beginning of that period; that is to say, $\left(1-\delta_{H}\right)$ is the marginal, as well as the average, propensity to spend out of wealth.

Now, using the demand functions which are derivable from (7a), we obtain the following demands:

$$
c_{T t}=\alpha_{H T} Z_{t} / p_{F T t}
$$

and

$$
c_{H N t}=\alpha_{H N} Z_{t} / q_{H N t} .
$$

Applying a similar procedure to problem ( $\left.3^{\prime}\right)$, we obtain the following demands by the foreign country:

$$
\begin{gathered}
c_{T t}^{*}=\alpha_{F T} Z_{t}^{*} / p_{F T t}, \\
c_{F N t}^{*}=\alpha_{F N} Z_{t}^{*} / p_{F N t}, \\
Z_{t}^{*}=\left(1-\delta_{F}\right)\left(\frac{\delta_{F}^{t}}{d_{t}} W_{0}^{*}\right),
\end{gathered}
$$

and

$$
W_{0}^{*}=\sum_{t=0}^{\infty} d_{t}\left(p_{F T t} Q_{F T}+p_{F N t} Q_{F N}\right)+\left(\bar{B}_{H 0} / e_{0}\right)+\bar{B}_{F 0} .
$$

Observe that the sum of the wealth variables $W_{0}+W_{0}^{*}$ equals the present value of the world's output (see [9] and [15b]). Hence, one country's liability is the other country's asset.

Using (6) and the equilibrium conditions in commodity markets, combined with the demands (11)-(14), we obtain:

$$
\begin{gathered}
p_{F T t} Q_{H T}+q_{H N t} Q_{H N}=\bar{M}_{H t} / e_{t}, \\
p_{F T t} Q_{F T}+p_{F N t} Q_{F N}=\bar{M}_{F t}, \\
q_{H N t} Q_{H N}=\alpha_{H N} Z_{t}, \\
p_{F N t} Q_{F N}=\alpha_{F N} Z_{t}^{*},
\end{gathered}
$$

and

$$
p_{F T t}\left(Q_{H T}+Q_{F T}\right)=\alpha_{H T} Z_{t}+\alpha_{F T} Z_{t}^{*}
$$

Conditions (17) are equilibrium conditions in nontraded-goods markets, while (18) is an equilibrium in the market for traded goods. Observe that, given the net wealth variables $W_{0}$ and $W_{0}^{*},(16)-(18)$, together with (10) and (15a), determine the equilibrium time path of prices, exchange rates, and the foreign interest rate factors. (The domestic interest rate factors can be derived using the interest rate parity condition.) Combining (10) and (15a) with (16b), (17b), and 
(18), we obtain:

$$
\begin{aligned}
d_{t}= & \bar{M}_{F T}^{-1}\left[\theta_{F T} \alpha_{H T}\left(1-\delta_{H}\right) W_{0} \delta_{H}^{t}\right. \\
& \left.+\left(\alpha_{F N}+\theta_{F T} \alpha_{F T}\right)\left(1-\delta_{F}\right) W_{0}^{*} \delta_{F}^{t}\right], t=0,1, \ldots,
\end{aligned}
$$

where $\theta_{F T}=Q_{F T} /\left(Q_{H T}+Q_{F T}\right)$ is the share of foreign traded goods in the world supply of traded goods.

In order to have positive foreign interest rates in all periods, the stock of foreign money must not decline too fast. This is seen from (19) by observing that the expression in the brackets declines over time $\left(0<\delta_{H}, \delta_{F}<1\right)$, while $\bar{M}_{F t}$ is the stock of foreign money in circulation at the beginning of period $t$. Clearly, if foreign money increases over time, $d_{t}$ declines over time, which implies positive interest rates in all periods. We assume that the money supply behaves so as to assure positive interest rates. ${ }^{5}$ Observe also that there is an initial condition $d_{0}=1$, which must be satisfied. We take care of this condition at a later stage.

Finally, consider the Fisher equation. Since $\left(1+i_{F t}\right)=d_{t} / d_{t+1}$, equation (19) implies $\lim _{t \rightarrow \infty}\left(1+i_{F T}\right)=\lim _{t \rightarrow \infty}\left(\bar{M}_{F t+1} / \bar{M}_{F t}\right) / \max \left(\delta_{H}\right.$, $\left.\delta_{F}\right)$, provided this limit exists. Suppose the rate of foreign monetary expansion goes to a finite limit $\mu_{F}$ and let $\delta_{k}=1 /\left(1+\rho_{k}\right)$. Then $1+i_{F t}$ approaches $\left(1+\mu_{F}\right)\left[1+\min \left(\rho_{H}, \rho_{F}\right)\right]$, which means that the long-run nominal interest rate equals (approximately) the rate of monetary growth plus the minimal rate of time preference. The minimal rate of time preference determines the long-run real interest rate. Here, in the long run, the Fisher equation holds; that is, in the long run the real interest rate equals the nominal rate of interest minus the rate of inflation. As we will show later on, the rate of price increase is, in the long run, the same for every good. Hence, it does not matter which price index is used to calculate the rate of inflation. This also means that the real interest rate is the same in terms of each commodity and is identical across countries. However, during the adjustment process, relative commodity prices change systematically, and real interest rates differ for different commodities. In this case, the real interest rates, as commonly calculated, are not equal across countries during the adjustment process, except in special cases. Namely, the difference between the nominal rate of interest and the rate of

\footnotetext{
${ }^{5}$ Negative interest rates are clearly not possible in an equilibrium, because they imply an infinite excess demand for debt. Zero interest rates are, however, possible. With a zero interest rate on a particular money-denominated debt, this money becomes a perfect substitute for debt for store-of-value purposes. However, unlike in Helpman and Razin (1979, sec. 1) and Kareken and Wallace (1981), this need not lead to indeterminacy of prices and exchange rates, due to the fact that here only money is used for transaction purposes.
} 
inflation-when the rate of inflation is calculated with the aid of a general price index-is not the same in every country.

Now consider equilibrium prices and exchange rates. Combining (18) with (19), (10), and (15a), we obtain the time path of traded goods' prices:

$$
p_{F T t}=\frac{\bar{M}_{F t}}{Q_{H T}+Q_{F T}} \frac{\alpha_{H T} Z_{t}+\alpha_{F T} Z_{t}^{*}}{\theta_{F T} \alpha_{H T} Z_{t}+\left(\alpha_{F N}+\theta_{F T} \alpha_{F T}\right) Z_{t}^{*}} .
$$

From (16b), (17b), (19), (10), and (15a), we calculate the time path of prices of the nontraded goods:

$$
q_{H N t}=\frac{\bar{M}_{F t}}{Q_{H N}} \frac{\alpha_{F N} Z_{t}}{\theta_{F T} \alpha_{H T} Z_{t}+\left(\alpha_{F N}+\theta_{F T} \alpha_{F T}\right) Z_{t}^{*}}
$$

and

$$
p_{F N t}=\frac{\bar{M}_{F t}}{Q_{F N}} \frac{\alpha_{F N} Z_{t}^{*}}{\theta_{F T} \alpha_{H T} Z_{t}+\left(\alpha_{F N}+\theta_{F T} \alpha_{F T}\right) Z_{t}^{*}} .
$$

The exchange rate is calculated from (16a), (20), and (21):

$$
e_{t}=\frac{\bar{M}_{H t}}{\bar{M}_{F t}} \frac{\alpha_{F N} Z_{t}^{*}+\theta_{F T}\left(\alpha_{H T} Z_{t}+\alpha_{F T} Z_{t}^{*}\right)}{\alpha_{H N} Z_{t}+\theta_{H T}\left(\alpha_{H T} Z_{t}+\alpha_{F T} Z_{t}^{*}\right)} \equiv \frac{\bar{M}_{H t}}{\bar{M}_{F t}} K\left(Z_{t}, Z_{t}^{*}\right) .
$$

The exchange rate equals the relative supply of monies divided by the relative real demand for monies. Here, there exists only a transactions demand for money. For example, $\alpha_{F N} Z_{t}^{*}$ is the foreign country's demand for foreign money needed to purchase nontraded goods, while $\alpha_{H t} Z_{t}+\alpha_{F T} Z_{t}^{*}$ is total world spending on traded goods, with a fraction $\theta_{F T}$ falling on foreign-made traded goods, which generates a corresponding demand for foreign money. The relative real demand for money, $K\left(Z_{t}, Z_{t}^{*}\right)$, can be written as:

$$
K\left(Z_{t}, Z_{t}^{*}\right) \equiv \frac{\theta_{F T} \alpha_{H T} Z_{t}+\left(\alpha_{F N}+\theta_{F T} \alpha_{F T}\right) Z_{t}^{*}}{\left(\alpha_{H N}+\theta_{H T} \alpha_{H T}\right) Z_{t}+\theta_{H T} \alpha_{F T} Z_{t}^{*}}
$$

Since $\theta_{F T} \alpha_{H T}<\alpha_{F N}+\theta_{F T} \alpha_{F T}$ and $\theta_{H T} \alpha_{F T}<\alpha_{H N}+\theta_{H T} \alpha_{H T}, K(\cdot)$ is decreasing in $Z_{t}$ and increasing in $Z_{t}^{*}{ }^{6}$

In order to understand the behavior of prices and exchange rates, consider the case $\delta_{H}>\delta_{F}$. In this case, the foreign rate of time preference is larger than the home-country rate of time preference. For present purposes, assume also that there are no changes in the supply of monies. This implies (via [10] and [15a]) that home spending-measured in terms of foreign currency-increases over

\footnotetext{
${ }^{6}$ Observe that $\theta_{F T} \alpha_{H T}-\alpha_{F N}-\theta_{F T} \alpha_{F T}=-1+\theta_{F T} \alpha_{H T}+\theta_{H T} \alpha_{F T}$. The last two terms represent a weighted average of $\alpha_{H T}$ and $\alpha_{F T}$, both smaller than one. Hence, the weighted average is also smaller than one.
} 
time, while foreign spending-also measured in terms of foreign currency-declines over time. ${ }^{7}$ These shifts in spending increase the demand for nontraded goods at home and reduce the demand for nontraded goods abroad, which results in an appreciation of the real exchange rate at home and a depreciation of the real exchange rate abroad. ${ }^{8}$ Moreover, the increased demand for home nontraded goods increases the domestic currency price of nontraded goods, which requires more home money for transactions in the market for nontraded goods. This leaves less home money for transactions with home firms producing traded goods, thereby reducing the home currency price of traded goods. In the foreign country, nominal prices move in the opposite direction. Since the foreign price of traded goods rises while the domestic price falls, the exchange rate appreciates at a rate that exceeds the rate of change (in absolute value) of either price of traded goods. In the limit, all prices rise at the rate of money growth.

Observe that in the present model, spending is proportional to wealth (see eq. [10] and the subsequent discussion). Hence, as we show in Appendix A the country with rising spending (in the present example the home country) experiences a surplus on current account (accumulation of wealth), while the country with declining spending experiences a deficit on current account (decumulation of wealth). This means that deficits on current account are associated with depreciations of the real, as well as the ordinary, exchange rate, while surpluses on current account are associated with appreciations of the real and the ordinary exchange rate.

If there is growth in money supplies, the preceding discussion remains valid but needs a slight reinterpretation. Everything that we said about home prices should be interpreted as applying relative to the trend in home money growth, while for foreign prices the relative yardstick is foreign money growth. Finally, the behavior of the exchange rate is relative to the differential trend in rates of money growth. The trend in real exchange rates is independent of monetary policies that are fully anticipated.

We close this section with a discussion of price indices. First, consider the GNP deflator. Since all money is used for transaction purposes and outputs are fixed, the rate of change in the GNP deflator in each country equals the rate of growth of its money supply. ${ }^{9}$ Since the

\footnotetext{
${ }^{7}$ However, independent of money growth, the spending ratio $Z_{t} / Z_{t}^{*}$ rises over time. For $\delta_{H}<\delta_{F}$ this pattern is reversed and so are all other patterns discussed below.

${ }^{\gamma}$ For a similar result see Razin (1980).

${ }^{9}$ The foreign country's GNP deflator in period $t$, with the base period being $t=0$, is $\left(p_{F T t} Q_{F T}+p_{F N t} Q_{F N}\right) /\left(p_{F T 0} Q_{F T}+p_{F N 0} Q_{F N}\right)$. With use of $(6 \mathrm{~b})$, this GNP deflator reduces to $\bar{M}_{F t} / \bar{M}_{F 0}$.
} 
rate of change in the exchange rate is not equal to the differential in the rates of growth of money supplies (unless $\delta_{H}=\delta_{F}$ ), purchasingpower parity (PPP) on GNP deflators does not hold, except in the limit (as $t$ goes to infinity). If, say, the home country is running a surplus on current account, the difference between the rate of increase in its GNP deflator and the GNP deflator of the foreign country will exceed the rate of depreciation of the home currency.

Now the rate of change in the GNP deflator is not equal to the rate of change in the consumer price index (except in the limit as $t$ goes to infinity). For the utility functions we have used there is an exact cost of living index, which is $P_{F t}=\left(p_{F T t}\right)^{\alpha} F\left(p_{F N t}\right)^{\alpha}$ for the foreign country. Let us call this index the CPI. A similar index is defined for the home country. It is shown in Appendix B that the CPI increases faster than the rate of monetary expansion in the country that runs a deficit on the trade account (not the current account!) if it also has a higher rate of time preference, and it rises more slowly than the rate of monetary expansion in the other country. If the deficit country has a lower rate of time preference, its CPI increases more slowly than its rate of money growth with the opposite taking place in the surplus country.

\section{Responses to Monetary Shocks}

We described in the previous section the time paths of prices, exchange rates, and interest rates. These time paths were based on the assumption that the economy evolves along a perfect-foresight equilibrium path. Observe, however, that our equilibrium time path depends on the values of $W_{0}$ and $W_{0}^{*}$, which represent present-value wealth of each country. These are endogenous variables, which depend on the equilibrium time paths of prices, exchange rates, and interest rates. This dependence is of no consequence for the qualitative description of the intertemporal equilibrium but is of major importance for the description of responses of the economy to shocks. Hence, we need to find a fixed point of $\left(W_{0}, W_{0}^{*}\right)$. Having found this fixed point, we consider unanticipated monetary shocks as well as anticipated monetary shocks.

In order to solve for $W_{0}$ and $W_{0}^{*}$, we must also solve simultaneously for the exchange rate in period zero. We form, therefore, a threeequation system which enables an explicit solution.

From (10), (15), (16b), and (19), we obtain:

$$
\theta_{F T} \alpha_{H T} W_{0}-\theta_{H T} \alpha_{F T} W_{0}^{*}+\bar{B}_{H 0} e_{0}^{-1}=-\bar{B}_{F 0} .
$$

Now, imposing the initial condition $d_{0}=1$, we obtain from (19):

$$
\theta_{F T} \alpha_{H T}\left(1-\delta_{H}\right) W_{0}+\left(\alpha_{F N}+\theta_{F T} \alpha_{F T}\right)\left(1-\delta_{F}\right) W_{0}^{*}=\bar{M}_{F 0} .
$$


Finally, evaluating (23) at $t=0$, and using (10), (15a), and (26), we obtain:

$$
\left(\alpha_{H N}+\theta_{H T} \alpha_{H T}\right)\left(1-\delta_{H}\right) W_{0}+\theta_{H T} \alpha_{F T}\left(1-\delta_{F}\right) W_{0}^{*}-\bar{M}_{H 0} e_{0}^{-1}=0 .
$$

Equations (25)-(27) provide a system of linear equations in $W_{0}, W_{0}^{*}$, and $e_{0}^{-1}$. It is immediately clear from this system that the solution does not depend on the course of monetary policies beginning with period 1. Hence, anticipated changes in monetary policy have no real effects, since we have shown in the previous section that real variables depend only on this triple (given the parameters of the system).

This observation is important because it had been argued in the literature that a change in the rate of monetary expansion (which means, in effect, a change in future quantities of money with no effect on the present stocks), as well as a future once and for all change in the quantity of money, have immediate effects on the exchange rate as well as real effects on the equilibrium time path along which the economy evolves (see, e.g., Calvo and Rodríguez 1977; Dornbusch and Fischer 1980; and Liviatan 1981). ${ }^{10}$ In the present framework, effects of this nature do not exist. This finding is in line with the findings in Helpman (1981). It is, for example, easy to see that an anticipated increase in the money supply of the home country in period $t$ increases the exchange rate in period $t, e_{t}$, by the rate of increase in the stock of money, while an anticipated increase in the foreign money supply reduces the exchange rate in period $t$ by the rate of increase in the stock of money. The exchange rate does not change in periods in which there are no changes in the stocks of monies.

Our results concerning the effects of anticipated monetary shocks on the current exchange rate and the evolution of real variables over time stem from the following features: $(a)$ there is no direct link between nominal variables and output levels; $(b)$ the velocity of circulation is constant; $(c)$ current spending depends on a definition of wealth which takes into account all future incomes; and $(d)$ there is perfect foresight. Under these circumstances, an anticipated monetary injection increases prices and the nominal exchange rate at the time of the injection, as well as the nominal interest rate in the preceding period. As a result, current real-wealth levels, and therefore also real-spending levels, do not change. Due to the constancy of the velocity of circulation, the real demand for money remains constant, too. Hence, there is no change in the exchange rate and in the real equilibrium; future exchange rates and interest rates bear the full burden of adjustment to anticipated monetary shocks.

10 These studies assume full price flexibility. Clearly, with price rigidity real effects are expected to arise. 
In all the studies cited above, except Helpman (1981), the velocity of circulation is interest elastic, which implies an immediate link between anticipated monetary shocks and the current exchange rate. This, per se, need not affect real variables, unless it also generates wealth effects. In Calvo and Rodríguez (1977) and Dornbusch and Fischer (1980) these wealth effects arise from the fact that their wealth variable does not take into account future incomes. Hence, the interaction between the interest-elastic velocity of circulation and the definition of wealth generates real effects. On the other hand, Liviatan (1981) does take into account the effects of future incomes on current spending (the neglect of this link is the subject of his criticism of Calvo and Rodríguez). However, since he introduces nominal assets as variables in the utility function, changes in the rate of monetary expansion produce real effects because they correspond to changes in the relative price of these "goods."

Our model can be extended in several directions so as to produce real effects of anticipated monetary changes. We would, for example, generate such effects by adding elastic labor supply with wages being paid at the end of each period (see Wilson 1979) or by introducing investment opportunities (see Helpman and Razin 1981b; and Stockman 1981). In both cases there exist distortions which depend on the course of monetary policy.

Once the real equilibrium depends on monetary policy, there exists also an incentive to change the payments period, which we have assumed to be fixed. However, changes in the payments period affect the velocity of circulation, thereby producing additional links between anticipated monetary policy and current exchange rates. There also exist, of course, links which can be introduced via Tobin-Baumol-type considerations in the demand for money, or links which arise from uncertainty and imperfect capital markets, as in Helpman and Razin (1982). While such elaborations may be very useful, they are outside the scope of the present study.

In the present system, unanticipated changes in the money supply have real effects which stem from the fact that they change the real value of international indebtedness. If the composition of debt is such that an unanticipated change in the money supply does not change the real indebtedness positions, then no real effects arise. For example, suppose $\bar{B}_{H 0}=0$; that is, there are no international debts denominated in home currency. Then it is easy to see from (25)-(27) that $W_{0}$ and $W_{0}^{*}$ will not change as a result of an increase in $\bar{M}_{H 0}$, and the exchange rate $e_{0}$ will increase in the same proportion as the increase in $\bar{M}_{H 0}$. This will have no real effect. On the other hand, if there is no international debt in foreign currency, then changes in $\bar{M}_{F 0}$ have no real effect. 
Without unanticipated changes in monetary policy, equations (25)-(27) provide a solution of the initial conditions which are needed for a complete description of the equilibrium time paths of all economic variables that we described in the previous section. Note that these time paths, as well as the initial conditions, are uniquely determined. This implies that with perfect foresight there is a unique equilibrium, and we need not assume that the economy chooses a particular perfect-foresight path (e.g., a stable-arm path) as is done in some studies (see, e.g., Calvo and Rodríguez 1977; Liviatan 1981). ${ }^{11}$

Now suppose that, at time $t=0$, the monetary authority of the home country unexpectedly increases the domestic money supply in period zero, with no change in the money supply in all subsequent periods. ${ }^{12}$ In order to compare the new equilibrium with the equilibrium that would have resulted had not the domestic money stock been increased, we need only to compute the change in $W_{0}$ and $W_{0}^{*}$ and then see how this affects the course of all variables that were discussed in the previous section. From (25)-(27) we calculate:

$$
\begin{gathered}
\frac{d W_{0}}{d M_{H 0}}=-\frac{1}{\Delta} e_{0}^{-1} \bar{B}_{H 0}\left(\alpha_{F N}+\theta_{F T} \alpha_{F T}\right)\left(1-\delta_{F}\right), \\
\frac{d W_{0}^{*}}{d \bar{M}_{H 0}}=\frac{1}{\Delta} e_{0}^{-1} \bar{B}_{H 0} \theta_{F T} \alpha_{H T}\left(1-\delta_{H}\right),
\end{gathered}
$$

and

$$
\begin{aligned}
\frac{d e_{0}^{-1}}{d \bar{M}_{H 0}} \frac{\bar{M}_{H 0}}{e_{0}^{-1}}= & \frac{1}{\Delta} \bar{M}_{H 0} \theta_{F T} \alpha_{H T}\left[\left(\alpha_{F N}+\theta_{F T} \alpha_{F T}\right)\left(1-\delta_{F}\right)\right. \\
& \left.+\theta_{H T} \alpha_{F T}\left(1-\delta_{H}\right)\right]
\end{aligned}
$$

where

$$
\begin{aligned}
\Delta= & -\bar{M}_{H 0} \theta_{F T} \alpha_{H T}\left[\left(\alpha_{F N}+\theta_{F T} \alpha_{F T}\right)\left(1-\delta_{F}\right)+\theta_{H T} \alpha_{F T}\left(1-\delta_{H}\right)\right] \\
& -\bar{B}_{H 0}\left(1-\delta_{F}\right)\left(1-\delta_{H}\right)\left[\alpha_{F T}\left(\alpha_{H N}+\theta_{H T} \alpha_{H T}\right)+\alpha_{H N} \theta_{F T} \alpha_{F T}\right] .
\end{aligned}
$$

It is explained in Appendix $\mathrm{C}$ that the existence of a solution with $W_{0}$ $>0$ and $W_{0}^{*}>0$ requires $\Delta<0$. Hence, we confine our discussion to this case only.

It is clear from (30) that the exchange rate depreciates as a result of

11 Our argument is valid only if an equilibrium exists. But an equilibrium fails to exist only if the solution to (25)-(27) yields a negative value of $W_{0}$ or $W_{0}^{*}$. This may indeed happen if either $\bar{B}_{H 0}$ or $B_{F 0}$ is too large in absolute value. In this case, one of the countries is not able to repay its debts even if its consumption is zero in every period (see Appendix C).

${ }^{12}$ In order to analyze a permanent monetary injection, we have to combine the following analyses with the analyses of an anticipated permanent addition to the stock of money in all future periods. 
a domestic monetary expansion. However, when we combine (30) with (31) it can be seen that the rate of depreciation is smaller than the rate of monetary expansion when $\bar{B}_{H 0}>0$ and larger than the rate of monetary expansion when $\bar{B}_{H_{0}}<0$. In the absence of indebtedness denominated in local currency, the rate of depreciation is precisely equal to the rate of domestic monetary expansion. Here the effects stem from a redistribution of wealth; with $\bar{B}_{H 0}>0$ home wealth increases and foreign wealth declines, while with $\bar{B}_{H_{0}}<0$ home wealth declines and foreign wealth increases.

One can use (28)-(30) to describe the shifts in the time profiles of prices, exchange rates, and interest rates that result from an unanticipated change in the domestic money supply. Here we describe only the possible effects on exchange rates (see, however, Helpman and Razin [1981a] for a discussion of prices, interest rates, and real exchange rates). If $\bar{B}_{H 0}>0$, then it is clear from (23) and (30) that, following the unexpected monetary expansion in period 0 , the entire profile of exchange rates shifts downward starting from period 1. However, in period 0 the exchange rate rises at a lower rate than the rate of money injection (a type of undershooting). If, however, $\bar{B}_{H 0}<$ 0 , then starting from period 1 the entire profile of exchange rates is higher than without the monetary injection; while in period 0 it is higher, but by a rate which exceeds the rate of the monetary injection (a type of overshooting). These two cases are described in figures 1 and 2 , where the heavy lines describe the path with the monetary injection, while the broken lines describe the path that would have obtained without the unanticipated monetary injection.

\section{Terms of Trade Effects}

So far we have discussed the adjustment process and the effects of monetary policies in a world economy in which there exists a single

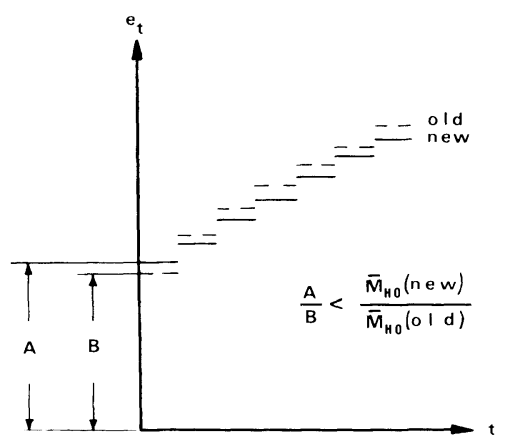

FIG. 1 


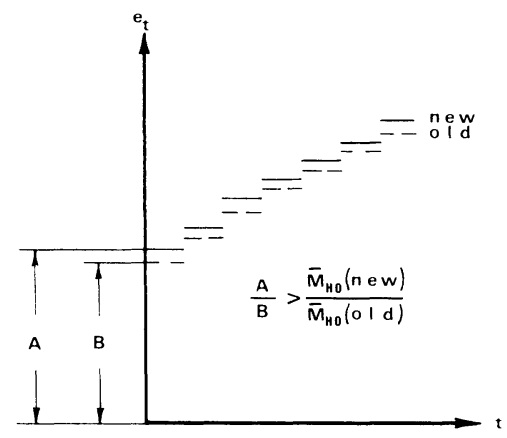

FIG. 2

traded good. This framework does not enable us to analyze the behavior of the terms of trade. However, apart from the intrinsic interest that exists in the behavior of the terms of trade, the presence of more than one traded good may alter a central link that was discussed in Section III, as well as in much of the existing literature, namely, the positive association between deficits on current account and exchange rate depreciations. An extension of our framework to the case of several traded goods (we shall employ two traded goods) enables us also to deal with the association between exchange rate movements and movements in the terms of trade (see, e.g., Stockman 1980). We shall show the precise links in both cases, and make it clear that the movements can be in different directions.

For the purpose at hand, we define the utility function for the home country (cf. eq. [7a]) to be:

$$
\begin{gathered}
u_{H}\left(c_{1}, c_{2}, c_{H N}\right)=\boldsymbol{\alpha}_{H 1} \log c_{1}+\boldsymbol{\alpha}_{H 2} \log c_{2}+\boldsymbol{\alpha}_{H N} \log c_{H N}+g_{H}, \\
\boldsymbol{\alpha}_{H 1}, \boldsymbol{\alpha}_{H 2}, \boldsymbol{\alpha}_{H N}>0, \boldsymbol{\alpha}_{H 1}+\boldsymbol{\alpha}_{H 2}+\boldsymbol{\alpha}_{H N}=1, \\
g_{H}=-\boldsymbol{\alpha}_{H 1} \log \alpha_{H 1}-\alpha_{H 2} \log \alpha_{H 2}-\alpha_{H N} \log \alpha_{H N},
\end{gathered}
$$

where $c_{1}$ and $c_{2}$ are two traded goods. The utility function for the foreign country is extended in a similar way.

Outputs of the traded goods are now $Q_{H 1}, Q_{H 2}, Q_{F 1}$, and $Q_{F 2}$, and we have new shares in world output levels, $\theta_{H i}=Q_{H i} /\left(Q_{H i}+Q_{F i}\right)$ and $\theta_{F i}=$ $Q_{F i} /\left(Q_{H i}+Q_{F i}\right), i=1,2$. Spending is defined as $Z_{t}=\Sigma_{i} p_{F i t} c_{i t}+q_{H N t} c_{H N t}$ for the home country, where $p_{F i t}$ is the price of traded good $i$ in terms of foreign currency. Foreign spending is similarly defined. Net-wealth variables $W_{0}$ and $W_{0}^{*}$ are defined as before-the present value of output minus debt-except that output now consists of three sectors instead of two.

It is straightforward to show that, in the present framework, each country continues to spend a fixed fraction of its wealth in every 
period, as described by (10) and (15a). Given this spending level, a country allocates its spending among all three goods according to the $\boldsymbol{\alpha}$ shares.

The equilibrium conditions (16) must be adjusted in order to reflect the existence of two traded goods. Thus, in (16a) and (16b), country $k$ 's value of output of traded goods, $p_{F T t} Q_{k T}$, should be replaced by $\Sigma_{i} p_{F i t} Q_{k i}$, and equation (18) should be replaced by a similar equation for every good $i$.

Employing the procedure that was used in Section III we can easily derive the counterparts of equations (19)-(24). For example, the counterpart of (19) will look the same as (19) except that $\theta_{F T} \alpha_{H T}$ will be replaced by $\Sigma_{i} \theta_{F i} \alpha_{H i}$ and $\theta_{F T} \alpha_{F T}$ will be replaced by $\Sigma_{i} \theta_{F i} \alpha_{F i}$. We abstain from repeating calculations and concentrate in what follows on new issues which arise due to the existence of terms of trade effects.

Let us begin with a discussion of the real exchange rate. This concept is, in fact, not well defined in the literature. Sometimes the reference is to the price of traded goods in terms of nontraded goods-as we have done in previous sections-while at other times the reference is to the price of foreign exchange in terms of exportables. The second concept is closely related to the terms of trade. We will reserve the term "real exchange rate" for the relative price of traded goods in terms of nontraded goods.

We have seen that, in the presence of a single traded good, the relative price of the traded good-the real exchange rate-rises over time in the country with a deficit on current account and falls in the surplus country. Thus, there is a positive association between real depreciations and deficits on current account. In order to discuss this issue in the present framework, one needs to employ a price index of traded goods. However, we can show that the price ratio of every traded good to the nontraded good increases over time in the deficit country and falls over time in the surplus country. Hence, independent of the price index, there exists a positive association between real depreciations and deficits on current account. ${ }^{13}$

In order to analyze the link between deficits on current account and the terms of trade, we compute the relative price of traded goods:

$$
\tau_{t} \equiv \frac{p_{F 1 t}}{p_{F 2 t}}=\frac{Q_{H 2}+Q_{F 2}}{Q_{H 1}+Q_{F 1}} \cdot \frac{\alpha_{H 1} Z_{t}+\alpha_{F 1} Z_{t}^{*}}{\alpha_{H 2} Z_{t}+\alpha_{F 2} Z_{t}^{*}} .
$$

${ }^{13}$ A straightforward calculation shows that $p_{F i t} / q_{H N t}=\left(Q_{H i}+Q_{F i}\right)\left[\alpha_{H i}+\alpha_{F i}\left(Z_{t}^{*} / Z_{t}\right)\right] /$ $\left(\alpha_{H N} Q_{H N}\right)$. The right-hand side is a decreasing function of $Z_{t} / Z_{t}^{*}$, while $Z_{t} / Z_{t}^{*}$ rises over time if the home country runs a surplus on current account, and it falls over time if it runs a deficit. 
It is clear from (32) that $\tau_{t}$ is an increasing function of $Z_{t} / Z_{t}^{*}$ when $\alpha_{H 1} / \alpha_{H 2}>\alpha_{F^{\prime} 1} / \alpha_{F 2}$, and it is a decreasing function of $Z_{t} / Z_{t}^{*}$ when $\alpha_{H 1} / \alpha_{H 2}<\alpha_{F 1} / \alpha_{F 2}$. Hence, if the home country runs a surplus on current account, that is, $Z_{t} / Z_{t}^{*}$ rises over time, then in the first case the relative price of good 1 rises, while it falls in the second case.

Observe that the relationship between deficits on current account and the shift in the relative price of the two traded goods depends only on the consumption parameters, $\boldsymbol{\alpha}$. Our conditions are, in fact, the same as in the transfer problem-the relative price of good 1 rises if the surplus country, whose spending rises, spends at the margin relatively more on good 1 than on good $2 .{ }^{14}$ However, in order to know the dynamics of the terms of trade, we need to know which country exports good 1 and imports good 2. This depends both on consumption parameters, $\boldsymbol{\alpha}$, and on the supply levels, $Q$. In fact, it is possible to produce cases in which one country exports both goods while the other imports both goods, which makes meaningless the definition of the terms of trade in that case. In closing this discussion, we wish to emphasize that it is clear from our analysis that even in cases in which the exportable good of a country is well defined, such as in the case in which each country produces only one traded good, there may exist a positive or a negative association between the terms of trade and the deficit on current account.

Let us now consider the nominal exchange rate. Using the present version, we calculate:

$$
e_{t}=\frac{\bar{M}_{H t}}{\bar{M}_{F t}} \cdot \frac{\left(\Sigma_{i} \theta_{F i} \alpha_{H i}\right) Z_{t}+\left(\alpha_{F N}+\Sigma_{i} \theta_{F i} \alpha_{F i}\right) Z_{t}^{*}}{\left(\alpha_{H N}+\Sigma_{i} \theta_{H i} \alpha_{H i}\right) Z_{t}+\left(\Sigma_{i} \theta_{H i} \alpha_{F i}\right) Z_{t}^{*}} .
$$

The expression following the ratio of stocks of money on the righthand side of (33) represents relative real demands for money-the ratio of the world's real demand for foreign money to the world's real demand for home money.

Differentiating (33), we find that the sign of $\partial e_{t} / \partial\left(Z_{t} / Z_{t}^{*}\right)$ is the same as the sign of:

$$
a=\Sigma_{i}\left(\theta_{F i} \alpha_{H i}+\theta_{H i} \alpha_{F i}\right)-1 .
$$

Observe that, either if there is a single traded good or if $\alpha_{H 1} / \alpha_{H 2}=$ $\alpha_{F 1} / \alpha_{F 2}$, then $a<0,{ }^{15}$ and changes in the nominal exchange rate are

14 The sign of $\left(\alpha_{H_{1}} / \alpha_{H 2}\right)-\left(\alpha_{F_{1}} / \alpha_{F 2}\right)$ is the same as the sign of $\left[\alpha_{H_{1}} /\left(1-\alpha_{H N}\right)\right]+\left[\alpha_{F^{\prime} 2} /(1\right.$ $\left.\left.-\alpha_{F N}\right)\right]-1$, which is the standard criterion in the transfer literature, where $\alpha_{k j}$ is the marginal propensity to spend on good $j$ in country $k$.

${ }_{15}$ To see that $a<0$ in these cases, observe that, in the first case, we have a weighted average of $\alpha$ 's minus one, which is negative because each $\alpha$ is smaller than one. In the second case, $\alpha_{H i}=\gamma \alpha_{F i}$ for some $\gamma>0$. However, summing over $i$ this equality, we find $\gamma=\left(1-\alpha_{H N}\right) /\left(1-\alpha_{F_{N}}\right)$. Substituting these into (34), one shows that $a=-(1-$ $\left.\Sigma_{i} \beta_{F i} \theta_{F i}\right) \alpha_{F N}-\left(\Sigma_{i} \beta_{F i} \theta_{F i}\right) \alpha_{H N}$, where $\beta_{F i}=\alpha_{F i} /\left(\alpha_{F 1}+\alpha_{F 2}\right)$. Since $\Sigma_{i} \beta_{F i} \theta_{F i}$ is a weighted average of $\theta_{F i}$, with each $\theta_{F i}$ being smaller than one, this expression is also smaller than one. Hence, $a<0$. 
positively associated with deficits on current account and, therefore, also with changes in the real exchange rate. Both cases fit into the discussion of Section III. The first is precisely the case discussed there, while in the second relative prices within the traded-goods sector do not change during the adjustment process, thereby enabling us to use a single Hicks composite of traded goods.

The interesting possibility that arises in the presence of more than one traded good is a negative association between changes in the exchange rate and deficits on current account-just the opposite of the association described above. This is illustrated by the case of complete specialization: $\theta_{F 1}=\theta_{H 2}=1, \theta_{F 2}=\theta_{H 1}=0$, in which $\alpha_{H 1}+$ $\alpha_{F 2}>1$. In this case, $a>0$, which implies that deficits on current account are associated with appreciations of the exchange rate and depreciations of the real exchange rate.

Intuitively, this result arises in cases in which each country has a relatively high marginal propensity to spend on the traded good which is in relative abundance in the other country. The existence of this element causes, during the course of the adjustment process, an increase in world demand for the deficit country's money and a decline in world demand for the surplus country's money, in order to facilitate the desired transactions in commodity markets. The existence of nontraded goods causes opposite shifts in the demand for money (as we explained in Sec. III). Hence, the negative association can arise only if the first element dominates. This is demonstrated by our example, but the argument is more general, as we demonstrate in what follows.

Let $\bar{\theta}_{i}=\left(\theta_{H i}+\theta_{F i}\right) / 2=1 / 2, i=1,2$, be the average $\theta_{i}$, and let $\bar{\alpha}_{i}=$ $\left(\alpha_{H i}+\alpha_{F i}\right) / 2, i=1,2, N$, be the average $\alpha_{i}$, where we average across countries. Then, the cross-country covariance between consumption shares and production shares is:

$$
\operatorname{cov}_{i}=\frac{1}{2} \sum_{k=H, F}\left(\theta_{k i}-\bar{\theta}_{i}\right)\left(\alpha_{k i}-\bar{\alpha}_{i}\right)
$$

Using (35), one can compute the relationship between $a$ and $\Sigma_{i} \operatorname{cov}_{i}$ as:

$$
a=-\bar{\alpha}_{N}-2 \Sigma_{i} \operatorname{cov}_{i} .
$$

It is clear from (36) that a necessary condition for $a>0$ is $\Sigma_{i} \operatorname{cov}_{i}<0$ and sufficiently large in absolute value so as to dominate $\bar{\alpha}_{N}$, which represents the effect of nontraded goods. Hence it is clear, as we have argued above, that sufficiently large negative cross-country correlations between marginal propensities to consume and a measure of relative availability of the good in the country can produce a negative association between deficits on current account and depreciations of 
the exchange rate. ${ }^{16}$ In such cases, if quantities of money do not change over time, appreciations of the real exchange rate will be associated with depreciations of the exchange rate and vice versa.

A final point concerns PPP. It is by now well known, and we have also discussed this issue in Section III, that PPP defined on broad price indices does not hold in the presence of nontraded goods (see, e.g., Viner 1937, p. 381). What is perhaps less widely understood is the fact that PPP need not hold even on traded goods when broad price indices are used. Take, for example, the case in which all goods are traded $\left(\bar{\alpha}_{N}=0\right)$ such that $\Sigma_{i} \operatorname{cov}_{i}<0$. Then $a>0$, and for economies with fixed stocks of money the exchange rate of the deficit country (deficit on current account) appreciates over time, despite the fact that PPP calculations using GNP deflators suggest a constant exchange rate. Now suppose that the deficit country employs a fixed rate of growth of money rule. Then, if the rate of growth of its stock of money is sufficiently low, PPP calculations using GNP deflators suggest that the deficit country's exchange rate should depreciate over time while, in fact, it appreciates over time. (Observe that, in this example, the deficit country has the higher rate of money growth, yet its exchange rate is appreciating.) Generally, as long as $a \neq 0$ there will be deviations from PPP based on GNP deflators, even in the absence of nontraded goods.

\section{Summary}

We have presented in this paper a complete two-country, floating exchange rate model which contains an explicit specification of the monetary mechanism. We showed that anticipated changes in the money supply have no real effects while unanticipated changes do have real effects. The real effects that are induced by unanticipated changes in the money supply stem from a redistribution of wealth that takes place as a result of changes in money stocks. The redistribution of wealth results from the existence of nominal obligations whose real value changes with prices. No real distribution takes place when changes in monetary policy are anticipated.

Our model generates interesting dynamics along the perfectforesight path. Suppose there is a single traded good and that the home country has a lower rate of time preference. Then it runs surpluses on current account and, over time, the price of traded goods rises at home more slowly than the rate of home money growth,

\footnotetext{
${ }^{16}$ An alternative expression for $a$ can be derived in terms of intracountry correlations between $\alpha$ and $\theta$ over all three goods (in this case $\theta_{H N}=1$ and $\theta_{F N}=1$ ). It can be shown that $a$ is proportional to minus the sum of these covariances where the sum is taken across countries.
} 
while the price of nontraded goods rises faster than the rate of home money growth. Its real exchange rate appreciates, while in the foreign country there are opposite trends. As a result, the rate of depreciation of the home currency (appreciation if negative) is smaller than the differential rate of money growth at home and abroad. Hence, despite the constancy of output levels, the rate of currency depreciation does not reflect the differential rates of monetary expansion. Moreover, since the GNP deflator rises in each country at the rate of money growth, PPP based on GNP deflators is invalid. It also does not hold if we use CPIs in our calculations, since in periods in which the home country has consecutive import surpluses its CPI rises more slowly than its rate of money growth, with the opposite taking place in the foreign country. We have also shown that the existence of nontraded goods is not necessary for the breakdown of PPP. In the presence of more than one traded good, PPP on, say, GNP deflators does not hold even in the absence of nontraded goods. This is due to changes in relative prices of traded goods.

The introduction of several traded goods was shown to give rise to new possibilities regarding exchange rate dynamics. With a single traded good, deficits on current account are associated with depreciations of the real exchange rate, as well as the exchange rate. In the presence of several traded goods, deficits on current account are necessarily associated with depreciations of the real exchange rate, but they may be associated with appreciations of the exchange rate. This may happen if there is a negative cross-country correlation between marginal propensities to spend on traded goods and their relative availability. In other words, if countries have high marginal propensities to spend on goods which are relatively abundant in their trading partner's country, this unusual outcome may appear. In such cases it may happen that a country with deficits on current account, whose stock of money grows faster than that of its trading partner, will experience appreciations of its exchange rate. The larger the share of spending on nontraded goods, the less likely is this outcome.

These results reveal macroeconomic implications of the demand for money that emerges from the microeconomics of our monetary mechanism. The feature we wish to emphasize is the dependence of the derived demand for money on microeconomic details such as the supply structure of the economies and propensities to spend on different goods. Such details, which play a major role in the pure theory of international trade, have traditionally been neglected in discussions of monetary problems. We believe that an integration of the traditional two branches of international economies (i.e., the monetary and the real branches) by means of explicit monetary mechanisms has much to offer. 
In order to demonstrate the importance of the monetary mechanism, consider an institutional structure which differs from ours. Suppose that instead of having to pay with the sellers' currency, one always pays with the buyers' currency. Namely, home residents buy all goods-independent of their source of production-with home money, while foreign residents buy all goods with foreign money. Then it can be shown that the exchange rate equation will be $e_{t+1}=$ $\left(\bar{M}_{H t} / \bar{M}_{F t}\right)\left(Z_{t}^{*} / Z_{t}\right)$, independent of the sectoral structure (however, these $Z_{t}$ 's need not be the same as the $Z_{t}$ 's in the present analysis). This specification seems to be in line with common modelings of the demand for monies in which it is assumed that residents of each country demand only their own country's money. Existing evidence (see Grassman 1973) suggests that in many cases the denomination of transactions is in the exporter's currency. It seems, therefore, that the specification adopted in the present study is as relevant as the alternative (see also Helpman and Razin [1981b] for a discussion of the alternative monetary mechanisms) ${ }^{17}$ Clearly, there is room for a systematic study of factors which determine the currency denomination of international transactions, particularly in view of the differences in implications that such varying modes of payments have for exchange rate behavior.

\section{Appendix A}

We show in this Appendix that $Z_{t} / Z_{t}^{*}$ rises over time if and only if $\delta_{H}>\delta_{F}$, which implies that the home country runs a surplus on current account. Using (9) and the definition of $\bar{B}_{k 0}, k=H, F$, we define period- $t$ wealth analogously to $W_{0}$. However, in order to have a common denominator, we define $\omega_{t} \equiv d_{t} W_{t}$ to be the value of period- $t$ wealth in present value terms (as of period 0 ). Formally, we define:

$$
\begin{aligned}
\omega_{t} & =\sum_{\tau=t}^{\infty} d_{\tau} Y_{\tau}-d_{t}\left(1+i_{F t-1}\right) B_{t-1} \\
& =\sum_{\tau=t}^{\infty} d_{\tau} Y_{\tau}-d_{t-1} B_{t-1},
\end{aligned}
$$

where $Y_{t}=p_{F T t} Q_{H T}+q_{H N t} Q_{H F}$ is the value of output and $B_{t}=B_{F t}+\left(B_{H t} / e_{t}\right)$ is the aggregate debt (measured in foreign currency). We utilize the interest rate parity condition (2) in this aggregation. Also, the period- $t$ analogue of (4) which holds in equilibrium with equality is:

$$
\sum_{\tau=t}^{\infty} d_{\tau} Z_{\tau}=\omega_{t} .
$$

${ }^{17}$ The evidence is on invoicing procedures, and we discuss actual payments. The two are not necessarily the same, but we know of no evidence concerning actual payments. 
From (A2) we obtain:

$$
\omega_{t}-\omega_{t+1}=d_{t} Z_{t}
$$

which, by use of (10), implies:

$$
\omega_{t}-\omega_{t+1}=\left(1-\delta_{H}\right) \delta_{H}^{t} W_{0} .
$$

This is a first-order difference equation with the following solution:

$$
\omega_{t}=\delta_{H}^{t} W_{0} \text {. }
$$

From (A4), period- $t$ current wealth equals $W_{t}=\omega_{t} / d_{t}=\left(\delta_{H}^{t} / d_{t}\right) W_{0}$, which implies via (10) $Z_{t}=\left(1-\delta_{H}\right) W_{t}$; that is, spending in period $t$ equals a fixed proportion $\left(1-\delta_{H}\right)$ of period- $t$ wealth.

In order to calculate the surplus on current account, we use (A1) to calculate: $d_{t-1} B_{t-1}-d_{t} B_{t}=\omega_{t+1}-\omega_{t}+d_{t} Y_{t}$. Using (A2) we obtain: $d_{t-1} B_{t-1}-$ $d_{t} B_{t}=-d_{t} Z_{t}+d_{t} Y_{t}$, which yields:

$$
B_{t-1}-B_{t}=Y_{t}-i_{F t-1} B_{t-1}-Z_{t} .
$$

Observe that, in the derivation of (A5), we have not used properties of the spending function; we have performed only accounting calculations. Hence, (A5) is a general relationship stating that the surpluses on current account, which equal national income (composed of $Y_{t}$ minus interest payments on foreign debts) minus spending (the right-hand side of [A5]), equal the decumulation over time of foreign debts.

It remains to be shown that declining debts are associated with an increase in spending and vice versa. In order to do so, we note that (A 1), (A4), and (10) imply $B_{t}=d_{t}^{-1} \sum_{\tau=t+1}^{\infty} d_{\tau} Y_{\tau}-\left[Z_{t} \delta_{H} /\left(1-\delta_{H}\right)\right]$. Now, using the definition of $Y_{\tau}$, as well as (19), (20), and (21), we obtain:

$$
B_{t}=\left[\theta_{H T} \alpha_{F T} Z_{t}^{*} \delta_{F} /\left(1-\delta_{F}\right)\right]-\left[\theta_{H F} \alpha_{H T} Z_{t} \delta_{H} /\left(1-\delta_{H}\right)\right] .
$$

We have seen in Section III that, given a constant stock of foreign money, a rising $Z_{t}$ over time is associated with $\delta_{H}>\delta_{F}$ and a falling $Z_{t}^{*}$ over time, and vice versa. Hence, it is clear from (A6) that, in this case, $B_{t}$ falls. This implies that surpluses on current account are associated with an increase in spending while deficits are associated with falling spending, all measured in terms of foreign currency. The real value of $B_{t}$ in terms of traded goods is $B_{t} / p_{F T t}$. Calculating $p_{F^{\prime} T}$ from (18) and substituting into (A6), we obtain:

$$
\begin{aligned}
B_{t} / p_{F T t}= & \left\{\left[\theta_{H T} \delta_{F}\left(1-\delta_{F}\right)^{-1} \alpha_{F T} Z_{t}^{*} /\left(\alpha_{H T} Z_{t}+\alpha_{F T} Z_{t}^{*}\right)\right]\right. \\
& \left.-\left[\theta_{F T} \delta_{H}\left(1-\delta_{H}\right)^{-1} \alpha_{H T} Z_{t} /\left(\alpha_{H T} Z_{t}+\alpha_{F T} Z_{t}^{*}\right)\right]\right\}\left(Q_{H T}+Q_{F T}\right) .
\end{aligned}
$$

Since from (10) and (15a) $Z_{t} / Z_{t}^{*}$ increases over time if and only if $\delta_{H}>\delta_{F}$, (A7) implies that $B_{t} / p_{F T t}$ declines over time if and only if $\delta_{H}>\delta_{F}$. Hence, rising $Z_{t} / Z_{t}^{*}$ is associated with surpluses on current account in terms of traded goods.

\section{Appendix B}

We discuss in this Appendix the behavior of the true cost-of-living index, which is defined for the foreign country as:

$$
P_{F t}=\left(p_{F N t}\right)^{\alpha_{F N}}\left(p_{F T t}\right)^{\alpha_{F T}} .
$$

A similar CPI can be defined for the home country. Using (20) and (22), we 
can write $P_{F t}$ in the following form:

$$
P_{F t}=\frac{\left[\alpha_{F^{\prime} N}\left(1-\delta_{F}\right)\left(Q_{F N}\right)^{-1}\right]^{\alpha_{F N}}}{\theta_{F T}\left(Q_{H T}+Q_{F T}\right)^{\alpha_{F T}}} \bar{M}_{F t} L\left[\left(W_{0} / W_{0}^{*}\right)\left(\delta_{H} / \delta_{F}\right)^{t}\right]
$$

where

$$
L(x)=\frac{\left[\alpha_{H T}\left(1-\delta_{H}\right) x+\alpha_{F T}\left(1-\delta_{F}\right)\right]^{\alpha_{F T}}}{\left\{\alpha_{H T}\left(1-\delta_{H}\right) x+\alpha_{F T}\left(1-\delta_{F}\right)+\left[\alpha_{F N}\left(1-\delta_{F}\right) / \theta_{F T}\right]\right\}} .
$$

Logarithmic differentiation of (B3) (where $\epsilon_{L}[\cdot]$ is the elasticity of $L[\cdot]$ ) yields:

$$
\begin{aligned}
\operatorname{sign} \epsilon_{L}(x) & =\operatorname{sign}\left\{\left[\alpha_{F T}\left(1-\delta_{F}\right) \theta_{H T} / \theta_{F T}\right]-\alpha_{H T}\left(1-\delta_{H}\right) x\right\} \\
& =\operatorname{sign}\left[\frac{Q_{H T}}{Q_{F^{T}}}-\frac{\alpha_{H T}\left(1-\delta_{H}\right)}{\alpha_{F T}\left(1-\delta_{F}\right)} x\right]
\end{aligned}
$$

Using $x=\left(W_{0} / W_{0}^{*}\right)\left(\delta_{H} / \delta_{F}\right)^{t},(11)$, and (13), we obtain:

$$
\operatorname{sign} \epsilon_{L}\left[\left(W_{0} / W_{0}^{*}\right)\left(\delta_{H} / \delta_{F}\right)^{t}\right]=\operatorname{sign}\left(\frac{Q_{H T}}{Q_{F T}}-\frac{c_{T t}}{c_{T t}^{*}}\right) .
$$

The right-hand side of (B4) is positive if the foreign country runs a deficit in its trade account, and it is negative if the foreign country runs a surplus in its trade account. This means that, if in periods $t$ and $t+1$ the foreign country runs a deficit in its trade account, then $P_{F t+1} / \bar{M}_{F t+1}>P_{F t} / \bar{M}_{F t}$ if $\delta_{H}>\delta_{F}$; and $P_{F t+1} / \bar{M}_{F t+1}<P_{F t} / \bar{M}_{F t}$ if $\delta_{H}<\delta_{F}$, and opposite for a surplus. In other words, the foreign CPI rises faster than its rate of monetary expansion between two consecutive periods, if the foreign country has an import surplus in both periods and a higher rate of time preference, or if it has an export surplus in both periods and a lower rate of time preference. Its CPI rises more slowly than its rate of monetary expansion between two consecutive periods, if it has an import surplus in both periods and a lower rate of time preference, or if it has an export surplus in both periods and a higher rate of time preference.

A similar result can be derived for the home country. Clearly, the CPI of one country rises faster than its rate of monetary expansion, while the other country's CPI rises more slowly than its rate of monetary expansion.

It is also clear from this discussion that if $W_{0} / W_{0}^{*}$ rises as a result of an unexpected monetary disturbance in the home country, then the foreign CPI rises in periods of foreign deficits and falls in periods of foreign surpluses. If $W_{0} / W_{0}^{*}$ falls, the foreign CPI falls in periods of foreign deficits and rises in periods of foreign surpluses. Similar conclusions can be derived for the home country for periods which follow the period in which the disturbance takes place. In the period in which the disturbance takes place, we have to add to the CPI the proportional effect of the unexpected monetary disturbance.

It is also easy to see from (B2) and (B3) that a once-and-for-all unexpected temporary change in the home money supply that redistributes wealth (i.e., changes $W_{0} / W_{0}^{*}$ ) has lasting effects on the rate of inflation in the foreign country in terms of the CPI. The rate of inflation as measured by the GNP deflator does not change. Similar conclusions apply to the home country, except that the rate of inflation as measured by the GNP deflator changes only in the vicinity of the time period in which the shock occurs. 


\section{Appendix C}

The purpose of this Appendix is to show that $\Delta<0$ (where $\Delta$ is defined as in [31]) is required for the existence of a solution in which net wealth of every country is positive. Clearly, negative wealth is inconsistent with an equilibrium, since consumption is proportional to wealth and consumption has to be nonnegative.

From (25)-(27) we can solve for $W_{0}, W_{0}^{*}$, and $e_{0}^{-1}$. The solution for the wealth variables is:

$$
\begin{aligned}
W_{0}= & \Delta^{-1}\left[\bar{B}_{H 0} \bar{M}_{F 0} \theta_{H T} \alpha_{F T}\left(1-\delta_{F}\right)+\bar{B}_{F 0} \bar{M}_{H 0}\left(\alpha_{F N}+\theta_{F T} \alpha_{F T}\right)\left(1-\delta_{F}\right)\right. \\
& \left.-\bar{M}_{H 0} \bar{M}_{F 0} \theta_{H T} \alpha_{F T}\right]
\end{aligned}
$$

and

$$
\begin{aligned}
W_{0}^{*}= & \Delta^{-1}\left[-\bar{B}_{H 0} \bar{M}_{F 0}\left(\alpha_{H N}+\theta_{H T} \alpha_{H T}\right)\left(1-\delta_{H}\right)-\bar{B}_{F 0} \bar{M}_{H 0} \theta_{F T} \alpha_{H T}\left(1-\delta_{H}\right)\right. \\
& \left.-\bar{M}_{H 0} \bar{M}_{F 0} \theta_{F T} \alpha_{H T}\right],
\end{aligned}
$$

where (compare with [31]):

$$
\begin{aligned}
\Delta= & -\bar{M}_{H 0} \theta_{F T} \alpha_{H T}\left[\left(\alpha_{F N}+\theta_{F T} \alpha_{F T}\right)\left(1-\delta_{F}\right)+\theta_{H T} \alpha_{F T}\left(1-\delta_{H}\right)\right] \\
& -\bar{B}_{H 0}\left(1-\delta_{F}\right)\left(1-\delta_{H}\right)\left[\alpha_{F N}\left(\alpha_{H N}+\theta_{H T} \alpha_{H T}\right)+\alpha_{H N} \theta_{F T} \alpha_{F T}\right] .
\end{aligned}
$$

Now, suppose $\Delta>0$; then (C3) implies:

$$
\bar{B}_{H 0}<-\frac{\bar{M}_{H 0} \theta_{F T} \alpha_{H T}\left[\left(\alpha_{F N}+\theta_{F T} \alpha_{F T}\right)\left(1-\delta_{F}\right)+\theta_{H T} \alpha_{F T}\left(1-\delta_{H}\right)\right]}{\left(1-\delta_{F}\right)\left(1-\delta_{H}\right)\left[\alpha_{F N}\left(\alpha_{H N}+\theta_{H T} \alpha_{H T}\right)+\alpha_{H N} \theta_{F T} \alpha_{F T}\right]} .
$$

However, with $\Delta>0$ equations (C1) and (C2) imply that $W_{0}$ and $W_{0}^{*}$ are positive if and only if the following two conditions are satisfied:

$$
\bar{B}_{F 0}>\frac{\bar{M}_{F 0} \theta_{H T} \alpha_{F T}\left[\bar{M}_{H 0}-\bar{B}_{H 0}\left(1-\delta_{F}\right)\right]}{\bar{M}_{H 0}\left(\alpha_{F^{\prime} N}+\theta_{F T} \alpha_{F T}\right)\left(1-\delta_{F}\right)}
$$

and

$$
\bar{B}_{F 0}<\frac{\left[\bar{M}_{H 0} \theta_{F T} \alpha_{H T}+\bar{B}_{H 0}\left(\alpha_{H N}+\theta_{H T} \alpha_{H T}\right)\left(1-\delta_{H}\right)\right] \bar{M}_{F 0}}{\bar{M}_{H 0} \theta_{F^{\prime}} \alpha_{H T}\left(1-\delta_{H}\right)} .
$$

From (C4) and (C5) we obtain $\bar{B}_{F 0}>0$, which implies that the right-hand side of (C6) has to be positive. But this is so if and only if the following holds:

$$
\bar{B}_{F 0}>-\frac{\bar{M}_{H 0} \theta_{F T} \alpha_{H T}}{\left(\alpha_{H N}+\theta_{H T} \alpha_{H T}\right)\left(1-\delta_{H}\right)} .
$$

Combining (C4) with (C7), we obtain:

$$
\begin{aligned}
\frac{\bar{M}_{H 0} \theta_{F T} \alpha_{H T}\left[\left(\alpha_{F N}+\theta_{F T} \alpha_{F T}\right)\left(1-\delta_{F}\right)+\theta_{H T} \alpha_{F T}\left(1-\delta_{H}\right)\right]}{\left(1-\delta_{F}\right)\left(1-\delta_{H}\right)\left[\alpha_{F N}\left(\alpha_{H N}+\theta_{H T} \alpha_{H T}\right)+\alpha_{H N} \theta_{F T} \alpha_{F T}\right]} \\
<\frac{\bar{M}_{H 0} \theta_{F T} \alpha_{H T}}{\left(\alpha_{H N}+\theta_{H T} \alpha_{H T}\right)\left(1-\delta_{H}\right)},
\end{aligned}
$$

which implies the contradiction $\theta_{H T} \alpha_{F T}\left[\theta_{F T} \alpha_{H T}\left(1-\delta_{F}\right)+\left(\alpha_{H N}+\theta_{H T} \alpha_{H T}\right)(1-\right.$ $\left.\left.\delta_{H}\right)\right]<0$. Hence, $\Delta>0$ leads to a contradiction and, therefore, $\Delta<0$. 


\section{References}

Boyer, Russell S. "Devaluation and Portfolio Balance." A.E.R. 67 (March 1977): 54-63.

$\rightarrow$ Calvo, Guillermo A., and Rodríguez, Carlos Alfredo. "A Model of Exchange Rate Determination under Currency Substitution and Rational Expectations." J.P.E. 85, no. 3 (June 1977): 617-25.

$\rightarrow$ Dornbusch, Rudiger, and Fischer, Stanley. "Exchange Rates and the Current Account." A.E.R. 70 (December 1980): 960-71.

$\rightarrow$ Grassman, Sven. "A Fundamental Svmmetry in International Payment Patterns.” J. Internat. Econ. 3 (May 1973): 105-16.

$\rightarrow$ Helpman, Elhanan. "An Exploration in the Theory of Exchange Rate Regimes.” J.P.E. 89, no. 5 (October 1981): 865-90.

Helpman, Elhanan, and Razin, Assaf. "Towards a Consistent Comparison of Alternative Exchange Rate Systems.” Canadian J. Econ. 12 (August 1979): 394-409.

- "Dynamics of a Floating Exchange Rate Regime." Working Paper no. 21-81, Foerder Inst. Econ. Res., 'Tel-Aviv Univ., May 1981. (a)

. "The Role of Saving and Investment in Exchange Rate Determination under Alternative Monetary Mechanisms." Working Paper no. 32-81, Foerder Inst. Econ. Res., Tel-Aviv Univ., September 1981. (b)

"A Comparison of Exchange Rate Regimes in the Presence of Imperfect Capital Markets.” Internat. Econ. Rev., vol. 22 (June 1982).

$\rightarrow$ Kareken, John, and Wallace, Neil. "On the Indeterminacy of Equilibrium Exchange Rates.” Q.J.E. 96 (May 1981): 207-22.

$\rightarrow$ Liviatan, Nissan. "Monetary Expansion and Real Exchange Rate Dynamics." J.P.E. 89, no. 6 (December 1981): 1218-27.

Razin, Assaf. "Capital Movements, Intersectoral Resource Shifts, and the Trade Balance." Seminar Paper no. 159, Inst. Internat. Econ. Studies, Univ. Stockholm, October 1980.

$\rightarrow$ Stockman, Alan C. "A Theory of Exchange Rate Determination." J.P.E. 88, no. 4 (August 1980): 673-98.

$\rightarrow$ "Anticipated Inflation and the Capital Stock in a Cash-in-Advance Economy." J. Monetary Econ. 8 (November 1981): 387-93.

Viner, Jacob. Studies in the Theory of International Trade. New York: Harper, 1937.

Wilson, Charles. "An Infinite Horizon Model with Money." In General Equilibrium, Growth, and Trade: Essays in Honor of Lionel McKenzie, edited by Jerry R. Green and José A. Scheinkman. New York: Academic Press, 1979. 